\title{
The Effectiveness of Metacognitive Teaching Strategies to Enhance Elementary School Pupils' Reading Skills in the Northern Border Areas of Saudi Arabia
}

\author{
Mogbel Aid K. Alenizi ${ }^{1} \&$ Mona Saleh Alanazi ${ }^{1}$ \\ ${ }^{1}$ Department of Education, College of Arts and Sciences, Rafha Male Campus, Northern Border University, \\ Rafha, Kingdom of Saudi Arabia \\ Correspondence: Mogbel Aid K. Alenizi, Department of Education, College of Arts and Sciences, Rafha Male \\ Campus, Northern Border University, P O Box 1189, Pin Code 91911, Rafha, Kingdom of Saudi Arabia. \\ E-mail: mugbe1999@hotmail.com
}

Received: May 2, 2016 Accepted: June 2, 2016 Online Published: July 13, 2016

doi:10.5539/ijel.v6n4p213 URL: http://dx.doi.org/10.5539/ijel.v6n4p213

\begin{abstract}
Difficulties in the fields of learning are among the most modern special educational fields and the fastest developing because of the extra concern from the parents and those concerned with children who show learning disorders, which cannot be explained by mental, physical or working disorders. Learning metacognition has short term benefits in the field of learning and teaching as it gives the individual the ability to connect between their learning successes to themselves. It increases their confidence with their ability and creates opportunities for them to use the lessons for the skills development, performance and assistance in transferring skills to others during work. The present study attempts to figure out the effectiveness of Metacognitive Strategies to further enhance students' reading skills. This empirical study shows significant results which further strengthen the proposed claims of such strategies which can be widely used to meet the learners' needs in a formal educational set up.
\end{abstract}

Keywords: metacognition, strategies, learning, disorders, reading, skills, Saudi Arabia

\section{Introduction}

Reading is classed as one of the main language skills as it plays an important role for everyone. The reading community has a unified thought and culture between its individuals. There is no doubt that reading as a language skills broaden the individual's spectrum of experience, makes their minds active, refreshes their thoughts, fulfils the love of beneficial curiosity to identify with oneself and know the rest of the world and what happens around it. Reading plays an important role in the life of the individual. Socially, it helps to connect between the individual and the community in terms of gaining direction, developing necessary skills within it and create a spirit of discussion in the community and respect for the values of others. From an educational perspective, it helps to increase the knowledge of the leaner. Through it, leaners can achieve the knowledge that helps them along the path to success in their school life. Thought it, it can help to resolve many of the problems that they face. It could even lead to resolving daily problems. In that light, reading comprehension skills are essential skills for all language learners. In learners' following, there is an opportunity for training for specific ideas, retaining knowledge, dealing with written text, identifying the topic for the text, identifying the unfolding of events and main ideas, the visible information and dealing with the thoughts that the readers' digest.

Most psychologists agree that the main area of learning disorders that has prevented progress has been in the second half of this century as learning disorders are considered to be the main areas that affect the different areas of life and affect people for their whole lives. Learning disorders then are not local difficulties that are restricted to a specific community or culture but have a worldwide effect. The US is considered to be the largest special educational hub in terms of the number of students who use these services. An American educational office pointed out that about $1.1 \%$ of those who need special education are from those with learning disorders (Miller \& Mercer, 1997, p. 21)

Reading is considered to be among the essential language skills through which individuals gain about $70 \%$ of their knowledge (Murray, 1998). Because students spend most of their daily hours learning, they need to read in 
order to learn all the topics (Al Hammouri \& Al Wahr, 2006). Reading is considered to be an active process that requires connection between different types of knowledge and skills to extract meaning from reading text (Fisher, 2002). Successful reading points to a clear connection between the meaning of the written text and the relationship between different parts of the text (Yang, 2002).

Touq et al. (2003) sees that metacognition points towards the skills that a learner monitors and uses, which uses various strategies in order to learn and remember. This develops and improves with age. This ability includes pinpointing the main concepts, changing strategies, predicting results, planning to divide time and effort, practising the knowledge, forming relationships and development, using memory aids and organising new knowledge in order for it to make it easier to remember. Many researchers confirm the importance of practising metacognitive and strategies in order to organise an effective learning environment, which allows students to learn and think beyond the knowledge. Students are in need of encouragement and support from outside in order to practise these ideas through carefully planned learning activities (Lin, 2001; Scardamalia \& Bereiter, 1991).

Metacognition has been described as being made up of various types. Flavell (1981) has confirmed the following contents of metacognition: identifying individual matters, the task and the strategy.

\subsection{Research Specification}

Reading is classed as one of the main language skills. It forms the window for the individual into the world. Through it, individuals gain knowledge and skills that help them to deal with their environments. Reading requires skills and procedures that help the individual to grasp the meaning of the text. Learning metacognitive strategies helps to improve the ability of students to learn, allowing them to think, organise themselves and for the learner to organise their time for monitoring and evaluating before and after learning processes. All of that in turn will reflect on the results especially with low achievers as it encourages them to learn by their abilities and what suits them. It improves their performance and work efficiency in order to gain planning skills, reasoning and comprehension. Because of the importance of this concept, this present study has aimed to identify the effectiveness of using an established program based on a metacognitive strategy in developing reading skills that elementary school pupil with learning disorders.

Through the recurring visits of the researchers of the elementary schools in the Kingdom of Saudi Arabia and those around it (Note 1). Notice that the teachers depend on lecturing and memorisation in their teaching and what that entails from forgetting and distortion on the part of the learner and "robotic learning" for the subject and their ability to recall it at the right time. This traditional method of teaching breeds a sense of alienation, discontentment and poor motivation for learning because the knowledge that they gain in this way does not form any benefit in their lives and rather ends their enthusiasm. It is also leads to deficiencies in learning that breeds generations that are unable to use their minds and are incompetent in thinking properly. Because of that there is no doubt that students should be taught how to think and that is through educational curriculums through study skill strategies that help the learner to gain knowledge, benefit from it and give it a meaning (Note 2). Because of that, it is important to training students how to think. Therefore, a learner is produced who has the ability to think independently in their learning and thus the learner becomes better at using language and more able to manage their learning by themselves. The study resolves around answering the following questions:

1) Firstly: how effective is a planned teaching curriculum for metacognitive strategies in developing the reading skills of elementary school pupils with learning disorders?

2) Secondly: to what extent do elementary school pupils use metacognitive procedures to develop reading skills for those with learning disorders?

Learning metacognition has short term benefits in the field of learning and teaching as it gives the individual the ability to connect between their learning successes to themselves. It increases their confidence with their ability and creates opportunities for them to use the lessons for the skills to improve their performance and assistance in transferring skills to others during work. It also prepares them with keys to improve their ability, organise their manners and build enthusiasm that is connected to the strategic growth, through analysing the problem and issuing rulings (Leather \& McLoughlin, 2001).

Rickey \& Stacy (2000, p. 915) have confirmed that metacognitive strategies help the learner to understand, learn effectively, and gain new thinking habit and cognitive skills that allow them to learn independently in future. It allows them to think, which helps to improve their ability to understand, reference, plan and manage problem solving.

Metacognitive are centred on the cerebral cortex. That is specifically in humans only. They are the ability to plan and be aware of the steps and strategies that we take to solve problems and the ability to use metacognition 
throughout our thoughts. There is no doubt that the competent thinker should use study skill strategies. This requires us as teachers to help the students to learn how to think about their thinking. Thinking of others also improves their learning (Saad, 2002).

This situation requires a new philosophy to develop the learning, which requires a review of students' ways of thinking since the first years of their lives. This does this not mean what the students learn but in reality means that the students learn how to think. With that, the main dissertation for the research is: simplifying learning by paying attention to curriculum articles, teaching and learning aimed at developing the nature of innovative strengths of learners and moving with from a culture of gaining knowledge to a culture of building knowledge, dealing with it and turning it into knowledge that includes discovering relationships and phenomena, allowing a transformation from a state of cognition to a state of metacognition, which is made up of thinking about knowledge, depth in comprehension, explaining and exploring knowledge (Al Jundi \& Sadiq, 2001). Jarwan (2002, p. 323) confirmed that learning thinking skills means helping students to hold onto their thoughts with vision and ambitions and raising their awareness to the extent that they are able to gain control over it and direct it with their own abilities and adjust its path in the direction that leads to achieving the goal. They prefer to work with the skills of metacognition in an indirect way until the foundation level.

Metacognition Strategies: "they are a group of processes that the learner uses to identify the activities, cognitive processes, means of learning and cognitive control that they use before and during and after learning to learn, understand, plan, manage, solve problems and other learning processes" (Henson \& Eller, 1999, p. 258; Shihab, 2000, p. 7).

Thinking: What is meant by thinking is that it is: "cognitive activities that distinguish humans from other living creatures. In these, mental pictures, knowledge, phrases, numbers signals, impressions and expresses that take the place of things, characters, situations and different events are used, which the person things about in order to understand a specific topic or situation" (Nasser, 2000, p. 18). Mayers (1988, p. 915) sees that the cognitive thoughts are made of 4 main thoughts and they are:

- Process: where it includes a group of working procedures or preparation inside the knowledge device

- Mental and cognitive activity: where the thoughts occur inside the human mind or the knowledge system and it is deal with by behaviours to indirectly solve problems

- Directed behaviour: meaning that it appears in the form of behaviours that direct towards behaviours that indirectly answer problems

- $\quad$ Synthetic and Analytical Activity

Newman (1995) has categorised thinking into the two levels:

- Firstly: levels of thinking about the world (lower level): these are the types of thinking that only require recalling previous knowledge such as recalling stored information in memory and paying attention to numbers connected to previous laws

- Secondly: higher level thinking: they are the types of thinking that require the learner to conclude and analyse information

Abdul (2001, p. 33) defines learning disorders as a delay, disorder or difficulty in one or more speech processes such as language, reading and writing. The calculation processes are a result of a defect in processing in the mind or behavioural problems. Children who have difficulties in learning because of that will be excluded from sensory defects, mental defects or deprivation (from studying). The first attempt at producing a specific definition for learning difficulties was in 1963 where Kirk gave the following definition:

"Learning difficulties point to delays, difficulties or deficiencies in one or more areas of speech, language, reading, spelling, writing or calculation processes because of a processing defect in the mind, emotional disorders, or behavioural difficulties. That results in children who are affected with learning difficulties resulting from sensory defects, mental defects or cultural deprivation" (Kirk \& Chalfant, 1988)

\section{Literature Review}

Abdul (2011) aimed to identify the effectiveness of a suggested program in light of metacognitive strategies to develop numerical skills and some higher level thinking skills in maths that pupils from the 5th elementary grade had. The study included a test group of a random sample, which included two schools: Mohammed Najeeb Community Elementary School and Othman ibn Affan Elementary School, the two of which are under the management of Al Bustanain and Dar Al Salam in the county of Cairo during the second semester of the academic year 2009-2010. The sample size for the study was 76 male and female students who were divided into 
control and test groups. The researcher prepared the suggested program that is based on the metacognitive strategies, which included "cooperative learning, examples, thinking aloud, self-questioning and reciprocal programs". Likewise there was a numeric test for maths and critical thinking, which aimed to measure the following skills "evaluation, extrapolation, hypothesise, explanation and making judgements". The following statistical methods were used "T Test, Black Test and Itasquare". The special results have shown that implementing the numeric tests have differences with statistical significance in favor of the test group, which benefits the metacognitive strategies. The study has advised of the importance of applying metacognitive strategies in learning processes because of the effective role that they play in developing thinking skills.

Mohammed (2010) identified the effectiveness of a program based on a metacognitive strategy to develop geography skills. The study used two strategies "self-questioning, the relationship between the question and the answer, thinking aloud and brainstorming". It specified "concept maps, diagrams, problem solving and prediction" on a sample of students from the first grade of high school in a summer school, Zaghlool under the management of Zaytoon in the county of Cairo. The study included a control group and test group. The researcher prepared a test for geography skills. The study used the $\mathrm{T}$ Text as a statistical method. The results showed differences with statistical significance between the average marks for students' performance in geography skills tests in favor of long term implementation with the contents of the program using metacognitive strategies. The study advised of the importance of paying attention to metacognitive strategies "self-questioning, the relationship between the question and the answer, thinking aloud and brainstorming" in high school levels because it develops geography skills well.

The study of Bayat \& Tarmizi (2010) aimed to evaluate the cognitive and metacognitive strategies while answering algebra questions between university students. The results of the study concluded that metacognitive strategies have a large effect on the performance of maths students, the opposite cognitive skills. The study of Ozsoya \& Ataman, 2009) aimed to identify the effectiveness of metacognitive strategies to achieve solutions for verbal questions. The results showed that there was a noticeable improvement in the metacognitive skills of the pupils in the group and their ability to solve verbal questions. The study of Jacobsea \& Harskampa (2009) developed metacognitive skills to solve maths problems using a computer program, so the effectiveness of the program developed the metacognitive skills and improved the achievement of the pupils in problem solving.

The study of Panaoura et al. (2009) also identified the effect of using a page on the Internet to improve students' own organisational skills in maths in light of examples, which is a metacognitive strategy. The results show that it helps to increase self-evaluation in order to learn how to react to difficulties when solving maths problems through examples. It is considered to be one of the ways of improving the performance of the students in learning about themselves and their maths performance.

Al Muqaddim (2009) aimed to identify the effectiveness of unity in maths using metacognitive strategies "self-questioning and brainstorming" in developing problem solving skills on a sample of students from the first regular elementary class in Al Amal Community School in the county of Al Wadi Al Jadeed. They were divided into a control and test group. The study followed the test curriculum. In order to verify the effectiveness of the study, a problem solving test was prepared and a measure for problem solving. The study used the following statistical methods "T Test and the Koder-Richardson Equation". The special results showed that there is a difference between the problem solving test for the control and test groups with statistically significant results in favor of the test group, which proves that using metacognitive strategies "self-questioning and brainstorming" helped to develop problem solving skills and increased their awareness in thinking and necessary methods to solve problems in various ways. It also initiated different new innovative ideas. The study advised of the importance of metacognitive strategies in education because it helps to initiate different new innovative ideas.

Qishta (2008) aimed to identify the use of metacognitive strategies to develop scientific concepts and life skills with science using a sample of students from the fifth elementary class in Jabaliya Elementary Boy's School for Refugees. They made up 74 students who were divided into two groups, control and test. The study followed the ordinary and test curriculum. In order to verify the aims of the study, a list of life skills were prepared, a test for the knowledge concepts, life skills tests and a register for the teachers. After the verification of the authenticity of the tools and their control, the two tests were performed before and after, on the study groups, control and test. The test used the Pearson Coefficient and T Test as statistical methods. The results showed that there is a statistically significant difference between the mean student marks in the control and test groups in testing their concept knowledge in favor of the test group. There was a statistically significant between the mean student marks in the control and test groups in the life skills test in favor of the test group. The studies have advised of the importance of the students practising metacognition skills and organising workshops for the teacher to train them to use metacognition strategies, whether before the service or after it until they are able to use it in 
teaching.

The study of (2008) aimed to identify the effectiveness of using a suggested established program for metacognition strategies in "SQ3R"; self-questioning, thinking aloud, concept mapping, reciprocal teaching, study skills, reciprocal reading on a sample of female students from the 2nd grade of high school in one of the high schools in the county of Cairo. The study followed a semi test curriculum. The study tools in the test were reading skills for studying, testing innovating reading skills, a list of innovative reading skills "fluency, flexibility, authenticity and specific details" and a list of suitable reading study skills for high school students and they are: "summarising, note taking, reading comprehension, producing questions, using a dictionary, using a library, using references and sources, scanning and speed reading". The results of the study showed that there is efficiency in sample learning in developing reading skills for studying. That is through the presence of differences with statistical significance between average female student marks for the two groups, the control and the test groups, in long term implementation for reading skills tests in favor of the test group that uses the metacognitive strategy "self-questioning, thinking aloud, concept mapping and reciprocal learning". The study has advised of the importance of using metacognitive strategies in pre reading skills, SQ3R because of what has from effects in developing reading".

Al Harithi (2008) aimed to identify the effectiveness of using reciprocal learning strategies to develop metacognitive strategies for high school students. The study followed a semi test curriculum with a random sample from Jarir High in the county of Jeddah through the first academic year 1428-1429. The sample consisted of 60 students who made up the control and test groups. The researcher used an achievement test in their studies to measure "planning reading, monitoring and controlling reading and evaluating reading skills" as a statistical means, ANCOVA. It was implemented before and after. The ANCOVA test was used and the study found that there were clear differences in the statistical significance in favor of the test group and for the effectiveness of reciprocal learning strategies in developing metacognitive skills. The study advised to use reciprocal learning strategies at the hands of teachers of reading classes and Arabic language tutoring and training the students of the teachers to use reciprocal learning strategies to teach reading and use it effectively during the educational learning process.

As for the study of Panaoura (2007) focused on the importance of learning and teaching in the light of metacognitive skills and the study found that repeat metacognitive tests have an effect on the student and self-performance.

As for the research of Tajika et al. (2007), it aimed to identify the effects of known metacognitive strategies with self-exploration in order to answer verbal questions in the elementary level. The results have shown that they are better than the self-exploration method in all the verbal questions and geometric transformations.

The study of Ali (2006) aimed to identify the effectiveness of knowledge strategies: "summarising, detailing, proving opinions, proving issues and questioning the author" and metacognition: "self-exploration, brainstorming, improving reading comprehension and its relationship to achievement in the philosophy subject with female student from the 3rd grade high school, K-W-L made up in the $6^{\text {th }}$ October High School for girls and Ilm Al Deen High School for girls in the county of Port Saeed where it is made up of the test group and the other is made up of the control group in the academic year 2005-2006. The researcher used a test for reading comprehension and another for achievement philosophy. It used the following statistical methods: "T Test, Pearson Coefficient, Chronbach's Alpha and the Koder-Richardson Equation". The results of the study showed that there is a difference with clear statistical significance between the mean marks for the control and test groups in the reading comprehension test and the long term benefits were for the test group, which proves the effectiveness of cognitive and metacognitive strategies in improving the reading comprehension and increasing the achievement level of the female students. The study advised of the importance of cognitive strategies and its importance in the High School stage because of the effective role that it plays in increasing the achievement level of the students.

Osman (2004) aimed to identify the effectiveness of one of the metacognitive strategies for "concept mapping" as a visual mental organisational strategy to connect between reading and writing. It was made up of learning tools to test achievement levels in reading and writing and programs that are made up of some reading texts. Each of them contains a group of concepts. The sample from the group is asked to summarise these texts and draw mind maps for the concepts that are included in each text. The results of this study have shown that the sample students answered using the concept mapping strategy whereby the students presented very good summaries and accurate mind maps. The study advised to use the concept mapping metacognitive strategy during the learning process. 
Mustafa (2004) aimed to identify the effects of using metacognitive strategies to develop reading comprehension skills for female students of the first elementary grade. The study was limited to some reading comprehension skills at the literal, deep and critical levels of comprehension. It was applied to the first elementary level as it was limited to the previous strategy for activating learning to develop reading comprehension skills. The tools for the study of reading comprehension skills were made up of essential reading comprehension skills for the first elementary grade. A T Test was used as a statistical method for the study. The results for the study showed that there is a clear different with statistical significance in favor of the test group in the reading comprehension test as a whole in the levels of literal, deep and critical levels of comprehension. It is possible to refer that to students using previous knowledge activity strategies. The study advised of the importance of training students in all stages of learning to use metacognitive strategies in teaching, studying their effects on achievement and the importance of training teachers to use modern teaching strategies including metacognitive strategies.

Fahmi (2003) aimed to identify the effectiveness of metacognitive strategies "self-questioning" in developing critical reading skills for female students in the 10th grade in Al Abbasiya High for girls in the county of Cairo. The study was limited to the second and third from the set reading text. In this study, the researcher used suitable critical reading skills for female students of the 10th grade, critical reading tests and a list of directed questions. The study reached the level of using metacognitive strategies to develop critical learning skills through learning meanings based on comprehension and reaching listening skills for other as they think aloud. The study reached the effectiveness of metacognitive strategies of self-questioning to develop differentiating skills between primary and secondary concepts, developing skills for evaluating evidence and criticising it and developing skills for identifying writers' aims. The study advised of the importance of considering teaching metacognitive strategies as one of the aims of High School and that working on developing the requirements of learning is above the electronic in terms "knowledge, awareness and control" that female High School students have.

Phakiti (2003) aimed to reduce gender differences in using knowledge and metacognitive strategies in reading English Language texts. The sample for the study was made of 384 from one of the Thai universities who put forwards a test for reading comprehension then replied to knowledge processes and metacognition. The results have shown that there is no different with statistical significance in reading comprehension or knowledge processes that favors gender differences whereas the males have been more successful than the females in terms of using metacognitive skills.

Hassam Al Deen (2002) aimed to measure the effectiveness of metacognitive strategies to develop reading comprehension and achievement in science subjects for pupils of the 2nd elementary level. Because of that the researcher chose the subject and prepared for it using metacognitive strategies to develop reading comprehension. In order to evaluate effectiveness of unity the researcher a reading comprehension test and another for achievement in science then applying these tools on a sample made up of 96 students (48 test students and 48 control students) from $2^{\text {nd }}$ elementary grade students in Sars Al Labban joint elementary school in Cairo. That was before unified teaching and after. The results have shown that there is a connection after studying it. There results show that the test group has outperformed their colleagues from the control group in all reading comprehension and achievement tests in levels of memory, understanding and application.

As for the study of Kapa (2002), it aimed to identify the effects of using metacognitive strategies on students to answer verbal questions through electronic learning. The results pointed to the effectiveness of applying metacognition in all problem solving stages better than their application in the final stages.

Koch (2001) prepared a study that aimed to identify the effects of using metacognitive strategies in developing reading comprehension in physics texts. For that a reading comprehension test was prepared for a sample group made up of 64 students (30 test students and 34 control students) in order to find similarities between them before using the metacognitive strategies and after. The results have shown that the students from the test group outperformed their colleagues from the control group students in the reading comprehension test.

As for the study of Shihab (2000), it came to identify the effectiveness of using metacognitive strategies for achievement in science and developing integrated learning process skills and innovative thinking among female students of the $3^{\text {rd }}$ elementary grade. To verify this, the researcher prepared a framework "Light and Sound" curriculum for the female students of the $3^{\text {rd }}$ elementary grade in the science subject in a way that supports the research sample to think about thinking and prepared an achievement test for unified concepts, a measure for integrated knowledge processes, test for innovative thinking and applied these tests before and after studying the unity of the sample, which was made up of 93 female students (among them 48 test students and 45 control students).

The results have shown that there is a clear statistically significant difference between the individuals of the test 
and control groups in all the various learning tools and that is in favor of the students of the test group.

Abu Alya \& Al Wahr (2000) aimed to identify the awareness of students of the Hashemite University of metacognition by preparing for exams and sitting them and their relationship to 3 variables. They are: the type of college, the academic year and the cumulative score. The study sample was made up of 374 male and female students who made up the 3 variables. The researchers used a test to measure the level of awareness of these concepts made up of 54 paragraphs and they verified the levels of validity and reliability. The study concluded that the students of the Hashemite University have average awareness of metacognitive concepts that are connected to preparation skills for exams and sitting them. The study also concluded that there is a statistically significant difference in favor of the cumulative marks. It was in favor of high cumulative marks and that there are clear differences in the academic year in favor of the third year whereas the study did not show any clear statistical difference that can favor the third variable, which is the college.

Cattell (1999) performed a study, which aimed to judge the effects of using metacognitive strategies on the achievement of 4 th grade students and their ability to comprehend written text. The sample for the study was made up of 18 children from schools in California who responded to pre and post tests and tests to measure the level of reading comprehension. The results showed that the metacognitive skills have on effect on the reading comprehension through their use of various metacognitive skills.

\section{Data Elicitation}

The researcher in this study used a semi test design (organising non-equivalent groups). A pre and post-test was applied onto each of the control and test groups.

\subsection{Study Group and Sample}

\subsubsection{Study Group}

The study group is made up of all the elementary level students in the government schools in the Kingdom of Saudi Arabia for the academic year 2014-2016.

\subsubsection{Study Sample}

The study sample was limited to 65 students from elementary level government school students in the Kingdom of Saudi Arabia who were chosen in a planned way. They were divided randomly into two classes. After that, one of the two classes was randomly divided as a test group of 35 . They were taught by using metacognitive strategies. The other group was a control group of 30 who were taught by the ordinary methods.

\subsection{Teaching Methodology}

The present has followed two methods

\subsubsection{Firstly (Computer Teaching Program)}

The researcher prepared a calculating program that includes a group from computer programs that were used as the teaching subject. Text, drawings, pictures, voices, videos, Marco media Director and exercise programs were used. The students interact with them. In addition to immediate feedback according to two answers including the teaching and evaluation activities have many interesting moments for higher level thinking skills and metacognitive strategies.

Activities were presented to motivate, excite and challenge students through following different types of activities in the program such as: adding text, pictures, video clips, sound clips and movement to expose the reality of the learning process.

Likewise, students were given rules for various types of knowledge that assist with the thinking process. That can be achieved through an International communication networks or websites in the school. This is what encourages metacognitive strategies and simulation programs on computers.

Confidence in the Computer Learning Program: Verification of the confidence in the specific program is based on a group of controls from specialist and experienced members of the teaching body at the universities in specialist curriculums and methods of teaching, self-educational methods, measurement evaluation as it took their feedback and suggestions and performed whatever amendments were required from the activities, exercises and any other suggestions.

\subsubsection{Secondly (Reading Section)}

Teachers were consulted in order to choose a reading section followed by 5 test questions. The passage was chosen from a reference book from the Ministry of Education and Learning. The aim of the reading section was 
that the students should read them. The skills and processes that were used during the answer were specified. That is through the answer on the measurement levels.

\subsection{Confidence of Performance}

In order to verify the truth of the test, it has been presented to a judging body with experienced and specialist members of the teaching body at the universities in specialist curriculums, teaching methods, measures and evaluation. Their comments and suggestions were taken into account and the necessary amendments and suggestions were made.

\subsection{Performance Control}

To verify the reading skills test and reading comprehension, control factors were used in two ways: the first is the method of application and repeating the application on a sample from the study group, outside the individual learners. Its number of individuals is 20 students with a time gap of two weeks between the first and second applications and methods and calculating Pearson Coefficient factors between the two applications for R Tests. The control factors for Koder-Richardson Equation are also used K-R20:

Table 1. Factors for internal awareness and control factors for reading skills

\begin{tabular}{lll}
\hline Topic & Internal Awareness Factors & Control \\
\hline Concept understanding & 0.76 & 0.72 \\
Deductive understanding & 0.82 & 0.79 \\
Critical understanding & 0.87 & 0.78 \\
Overall measurement & 0.82 & 0.76 \\
\hline
\end{tabular}

\subsection{Dealing with Difficulties and Differentiation}

As all the difficulty and differentiation factors were extracted for reading comprehension sections and it was reviewed; the difficulty factors ranged between 0.37 and 0.74 . The differentiation factors were between 0.35 and 0.71. The following table 2 clarifies that.

Table 2. Difficulty and differentiation factors for all the overall reading sections

\begin{tabular}{llllll}
\hline $\begin{array}{l}\text { Question } \\
\text { Number }\end{array}$ & $\begin{array}{l}\text { Difficulty } \\
\text { Factors }\end{array}$ & $\begin{array}{l}\text { Differentiation } \\
\text { Factors }\end{array}$ & $\begin{array}{l}\text { Question } \\
\text { Number }\end{array}$ & $\begin{array}{l}\text { Difficulty } \\
\text { Factors }\end{array}$ & $\begin{array}{l}\text { Differentiation } \\
\text { Factors }\end{array}$ \\
\hline 1 & 0.40 & 0.62 & 16 & 0.45 & 0.73 \\
2 & 0.37 & 0.45 & 17 & 0.65 & 0.69 \\
3 & 0.74 & 0.69 & 18 & 0.54 & 0.67 \\
4 & 0.45 & 0.71 & 19 & 0.65 & 0.57 \\
5 & 0.65 & 0.57 & 20 & 0.44 & 0.61 \\
6 & 0.44 & 0.61 & 21 & 0.42 & 0.51 \\
7 & 0.39 & 0.64 & 22 & 0.45 & 0.35 \\
8 & 0.46 & 0.65 & 23 & 0.39 & 0.64 \\
9 & 0.42 & 0.51 & 24 & 0.46 & 0.56 \\
10 & 0.45 & 0.35 & 25 & 0.43 & 0.69 \\
11 & 0.54 & 0.53 & 26 & 0.54 & 0.68 \\
12 & 0.54 & 0.67 & 27 & 0.52 & 0.41 \\
13 & 0.52 & 0.49 & 28 & 0.58 & 0.46 \\
14 & 0.58 & 0.47 & 29 & 0.69 & 0.58 \\
15 & 0.69 & 0.57 & Overall & $\mathbf{0 . 5 2}$ & $\mathbf{0 . 5 9}$ \\
\hline
\end{tabular}

\subsection{Study Variables}

The study was made up of the following variables: method of teaching (Using the computer learning program and ordinary methods), reading (It is defined as one of the calculation baselines for the female students' levels in the countable measures of this study).

\subsection{Statistical Analysis}

In order to answer the questions of the study, the mean and standard deviation values were extracted for the individual marks in the sample for the control and test groups and applying Paired Sample T Tests for the paired 
samples in order to identify the differences between the mean test group marks with pre and post study measurements and Independent Sample T Tests to identify between the two groups in the pre measurement for similarities and post measurements to identify the differences. After that, an ANCOVA test was performed to identify the effects of the computer learning program based on metacognitive strategies.

\section{Data Analysis, Discussion \& Implication}

This section contains a representation of the results of the study, which aims to identify the effectiveness of using a program based on metacognitive strategies in developing reading skills for elementary level pupils. What follows is a representation of the study results based on our questions:

The third question: How effective is using a program based on metacognitive strategies in developing reading skills for elementary level pupils?

To answer this question, the mean and standard deviation values had been outputted for the pre and post measurements for the control and test groups. An Independent T Test was applied for the independent samples to identify the differences between the two groups on the post measurement. The following table clarifies that. A Paired Sample T Test was applied for the paired samples to identify the differences between the average pre and post measurements for each group based on measuring reading skills. The following table 3 shows that.

An Independent Sample T Test to identify the results of the two groups in measuring the reading skills for the pre measurements

Table 3. Pre- measurement reading skills

\begin{tabular}{llllll}
\hline Group & Average & Standard Deviation & T Value & Degree of Freedom & Statistical Significance \\
\hline Control & 62.73 & 5.74 & 1.23 & 63 & 0.22 \\
Test & 61.20 & 4.25 & & & \\
\hline
\end{tabular}

The Table 3 above shows that the T Values are low and do not show statistical significance at the significance level $(\alpha \leq 0.05)$ for the pre measurement. This shows that there is a relationship between the control and test groups in the pre measurement.

Table 4. Post-measurement independent sample T Test results

\begin{tabular}{llllll}
\hline Group & Average & Standard Deviation & T Value & Degree of Freedom & Statistical Significance \\
\hline Control & 78.53 & 6.48 & 2.77 & 63 & 0.01 \\
Test & 83.40 & 7.51 & & & \\
\hline
\end{tabular}

The Table 4 shows that the T Value has statistical significance at the significance level $(\alpha \leq 0.05)$ between the control and test groups in the post measurement. The differences were in favor of the test group where the performance of the students in this group was better in the post measurement than the control group.

Table 5. Paired pre and post measurements for the control and test groups

\begin{tabular}{|c|c|c|c|c|c|}
\hline Group & Average & Standard Deviation & T Value & Degree of Freedom & Statistical Significance \\
\hline Control & 62.73 & 5.74 & 9.05 & 29 & 0.00 \\
\hline Test & 78.53 & 6.48 & & & \\
\hline Control & 61.20 & 4.25 & 15.54 & 34 & 0.00 \\
\hline Test & 83.40 & 7.51 & & & \\
\hline
\end{tabular}

The Table 5 shows that there is a statistically significant difference between the pre and post measurements for each of the groups in reading skills as the T Value for the test group was 15.54 with a significance of 0.00 . The differences were in favor of the post measurement. The $\mathrm{T}$ Value for the control group was 9.05 with a significance of 0.00 . The differences were in favor of the post measurement but it is noticed the progress level in the test group is better than the control group.

To identify the effectiveness of using a program based on metacognitive strategies in developing reading skills for elementary level pupils, an ANCOVA test was applied. The following table 6 shows that. 
Table 6. Results of the ANCOVA test to identify the differences between the groups in Pre \& Post measurement

\begin{tabular}{llllll}
\hline & Sum of the Boxes & Degrees of Freedom & Average Boxes & F Value & Statistical Significance \\
\hline Group & 346.39 & 1 & 346.39 & 6.89 & 0.01 \\
Pre-measurement & 21.70 & 1 & 21.70 & 0.43 & 0.51 \\
Error & 3116.17 & 62 & 50.26 & & \\
Actual amount & 3520.46 & 64 & & & \\
\hline
\end{tabular}

The Table 6 shows that there is a different with statistical significance at the significance level, 0.05 , following the group variables. The differences are in favor of the test group. The results also show that there is no difference in the reading skills measurement in the pre measurement. This confirms the similarity between the two groups in the pre measurements.

The second question: there is no statistically significant difference between the average marks of the control and test groups in the pre and post-tests in separate reading comprehension tests (literal, deductive and critical reading)?

In order to answer this question, the means and standard deviations were produced for the pre and post measurements for the control and test groups. An Independent Sample T Test was applied for the independent groups to identify the differences for post measurements. The following table clarifies that. The Paired Sample T Test was applied for the paired samples to identify the differences between the pre and post measurements for each group for measuring special metacognition by developing reading comprehension skills as the following table shows.

Table 7. Group level performance in developing reading comprehension skills

\begin{tabular}{lllllll}
\hline & Group & Average & $\begin{array}{l}\text { Standard } \\
\text { Deviation }\end{array}$ & T Value & $\begin{array}{l}\text { Degree of } \\
\text { Freedom }\end{array}$ & $\begin{array}{l}\text { Statistical } \\
\text { Significance }\end{array}$ \\
\hline Literal & Control & 30.20 & 2.78 & 0.25 & 63 & 0.80 \\
Understanding & Test & 30.40 & 3.53 & & & 0.52 \\
Deductive & Control & 43.80 & 4.68 & 0.65 & 63 & \\
Understanding & Test & 44.49 & 3.89 & & & 0.71 \\
Critical & Control & 20.97 & 2.01 & 0.37 & 63 & \\
Understanding & Test & 20.74 & 2.01 & & & \\
Overall Test & Control & 94.97 & 6.67 & 0.44 & 63 & \\
& Test & 95.63 & 5.40 & & & \\
\hline
\end{tabular}

The Table 7 shows that the T Test is low and not statistically significant at the significance level $(\alpha \leq 0.05)$ for the test for developing reading comprehension skills. This shows that there is similarity between the control and test groups in the pre-measurement.

Table 8. Post measurement results of the independent sample T Test of two groups

\begin{tabular}{lllllll}
\hline & Group & Average & $\begin{array}{l}\text { Standard } \\
\text { Deviation }\end{array}$ & T Value & $\begin{array}{l}\text { Degree } \\
\text { Freedom }\end{array}$ & $\begin{array}{c}\text { of } \\
\text { Statistical } \\
\text { Significance }\end{array}$ \\
\hline Literal & Control & 59.33 & 4.43 & 4.35 & 63 & 0.00 \\
Understanding & Test & 63.89 & 4.00 & & & \\
Deductive & Control & 85.23 & 5.88 & 4.09 & 63 & 0.00 \\
Understanding & Test & 92.00 & 7.25 & & & \\
Critical & Control & 40.30 & 3.68 & 6.05 & 63 & 0.00 \\
Understanding & Test & 45.71 & 3.53 & & & \\
Overall Test & Control & 184.87 & 6.82 & 6.12 & 63 & 0.00 \\
& Test & 199.97 & 11.94 & & & \\
\hline
\end{tabular}

The Table 8 shows that all the $T$ Values have statistical significance at the significance level $(\alpha \leq 0.05)$ between the control and test groups. The reading comprehension in this group was better in the post measurement. 
Table 9. Pre and post measurement results of the paired sample tests

\begin{tabular}{|c|c|c|c|c|c|c|c|}
\hline Group & Field & Level & Average & $\begin{array}{l}\text { Standard } \\
\text { Deviation }\end{array}$ & T Value & $\begin{array}{l}\text { Degree of } \\
\text { Freedom }\end{array}$ & $\begin{array}{l}\text { Statistical } \\
\text { Significance }\end{array}$ \\
\hline \multirow[t]{8}{*}{ Control } & Literal & Pre & 30.20 & 2.78 & 31.431 & 29 & 0.00 \\
\hline & understanding & Post & 59.33 & 4.43 & & & \\
\hline & Deductive & Pre & 43.80 & 4.68 & 33.697 & 29 & 0.00 \\
\hline & understanding & Post & 85.23 & 5.88 & & & \\
\hline & Critical & Pre & 20.97 & 2.88 & 22.287 & 29 & 0.00 \\
\hline & understanding & Post & 40.30 & 3.68 & & & \\
\hline & Overall test & Pre & 94.97 & 6.67 & 59.702 & 29 & 0.00 \\
\hline & & Post & 184.87 & 6.82 & & & \\
\hline \multirow[t]{8}{*}{ Test } & Literal & Pre & 30.40 & 3.53 & 33.28 & 29 & 0.00 \\
\hline & understanding & Post & 63.89 & 4.00 & & & \\
\hline & Deductive & Pre & 44.49 & 3.89 & 31.74 & 29 & 0.00 \\
\hline & understanding & Post & 92.00 & 7.25 & & & \\
\hline & Critical & Pre & 20.74 & 2.01 & 33.71 & 34 & 0.00 \\
\hline & understanding & Post & 45.71 & 3.53 & & & \\
\hline & Overall test & Pre & 95.63 & 5.40 & 45.19 & 34 & 0.00 \\
\hline & & Post & 199.97 & 11.94 & & & \\
\hline
\end{tabular}

The test group result above shows that there is a statistically significant difference in measuring developing reading comprehension skills between the pre and post measurements. The differences were in favor of the post measurement where the $\mathrm{T}$ Value for the literal understanding was 33.28 with a statistical significance of 0.00 . The mean value for the literal understanding in the pre measurement value was 30.40 whereas the mean value in the post measurement had risen to 63.89 .

The average for the deductive understanding in the pre measurement was 44.49 whereas the average for the post measurement had risen to 92.00 . The $\mathrm{T}$ Value for the deductive understanding reached 31.74 with a statistical significance of 0.00 . The difference was in favor of the post measurement. The average for the critical understanding in the pre measurement was 20.74 whereas the average had risen in the post measurement to 45.71 . The $\mathrm{T}$ Value for the critical understanding had reached 33.71 with a statistical significance of 0.00 . The difference was in favor of the post measurement.

As for the control group, the $\mathrm{T}$ Value was also statistically significant at a significance level of 0.05 . The difference was in favor of the post measurement. The level of different between the pre and post measurements was less than the test group, which showed greater differences in the post measurement.

In order to identify the effectiveness of using a program based on metacognitive strategies, an ANCOVA Test had been applied. The following table shows that.

Table 10. ANCOVA test results to identify the effectiveness metacognitive strategy

\begin{tabular}{lllll}
\hline & Sum of the Boxes & Degrees of Freedom & Average Boxes & $\begin{array}{c}\text { Statistical Value } \\
\text { Significance }\end{array}$ \\
\hline Group & 696.46 & 1 & 696.46 & 0.01 \\
Pre - measurement & 47.36 & 1 & 47.36 & 0.37 \\
Error & 6774.75 & 62 & 109.27 & 0.43 \\
Correct amount & 7500.62 & 64 & 696.46 & 0.51 \\
\hline
\end{tabular}

The Table 10 shows that there is a statistically significant difference at the significance level of 0.05 following the group variable at the post measurement. The difference was in favor of the test group. The results show that there is no difference in the measurements for the reading comprehension skills in the pre measurement. This confirms that there was similarity between the two groups in the pre measurement.

\section{Conclusion}

The above results show significant findings which support the effectiveness of metacognitive strategies, in terms of skills improvement of the learners with various learning disorders. However the study of metacognition has provided educational psychologists with insight about the cognitive processes involved in learning and what differentiates successful students from their less successful peers. It also holds several implications for 
instructional interventions, such as teaching students how to be more aware of their learning processes and products as well as how to regulate those processes for more effective learning. Metacognition enables students to benefit from instruction (Carr, Kurtz, Schneider, Turner, \& Borkowski, 1989; Van Zile-Tamsen, 1996) and influences the use and maintenance of cognitive strategies. While there are several approaches to metacognitive instruction, the most effective involve providing the learner with both knowledge of cognitive processes and strategies (to be used as metacognitive knowledge), and experience or practice in using both cognitive and metacognitive strategies and evaluating the outcomes of their efforts (develops metacognitive regulation). Simply providing knowledge without experience or vice versa does not seem to be sufficient for the development of metacognitive control (Livingston, 1996).

\section{References}

Abdul, H. A. (2010). Failiyyat Barnamij Muqtarih Fi Doh Istatayjiyyat Fi Ma Wara Al Marifa Litanmiyat Al Hass Al Adadi Wa Baad Maharat Al Tafkeer Al Ulya Fi Al RiyadiyyatLadayTalameeth Al Saf Al Khamis Al Ibtidai. Unpublished Master Dissertation, College of Education: Ain Al Shams University.

Abu Ilyan, M., \& Al Wahr, M. (2000). Darajat Wai Al Talaba Al Jamia Al Hashimiya Bi Al Marifa Ma Wa Al Marifa Al Mutaaliqa Bi maharat Al Ida Lil ImtihanatWallaqatThalik Bi Mustowahim Al Dirasi Wa Madiluhum Wa Al Kulliya Al Lati Yantamoon Ilaiha. Al Uloom Al Tarbawiya, 28(1), 1-14.

Al Hammouri, H., \& Al Wahar, M. (2006). Tatawwar Al Marifa Al Mutalliqa Bi Qiraat Al Uloom Laday Tullab Al Sufoof Min Al Sadislla Al Ashir. Al Uloom Al Tarbawiyya, 33(2).

Al Harithi, M. (2008). Faaliya Istikhdam Istratijiya Al Tadrees Al Ibtidai Fi Tanmiyat Maharat Ma Wara Al Marifa Fi Al Qira Laday Tullab Al Marhala Al Thanawiya. Unpublished Master Dissertation, College of Education: Umm Al Qura University.

Al Jundi, A., \& Sadiq, M. (2001). Faaliya Istikhdam Ma Wara Al Marifa Fi Tahseem Al MuallimWa Tanmiyat Al Tafkeer Al Ibtikari Laday Talameeth Al Saf Al Thani Al ItiyadiThaway Al Saat Al Aqliya Al Mukhtalifa, Al Mutamar Al Alami Al Khamis, Al Tarbiya Al Alamiya Lil Muwatina. Egyptian International Educational Society, 29(1). Ain Shams University, Egypt.

Al Muqaddam, S. (2009). Faaliyyat Wihdat Fi Al Uloom Bi Istikhdam Istratijiyyat Ma Wara Al Maarifa Fi Tanmiyat Maharat Hal Al Mushkilat Laday Talameeth Al Saf Al Awwal Al Itiyadi. Unpublished Master Dissertation, College of Education, Ain Al Shams University.

Al Qatayiri, S. M. (1996). Faaliyat Istratijiyyat Ma Wara Al Idrak Fi TanmiyatMaharatQirat Al Nass Wa Mayool Al Falsafiyya Bi Al Marhala Al Thanawiyya, Kulliyat Al Tarbiya Wa. Al ZaqazeeqMagazine, 27, 225-255.

Ali, W. (2006). Faaliyyat Istikhdam Al Istratijiyyat Al Maarifiyya Wa Ma Wara Al Maarifiyya Fi Tahseen Al Faham Wallaqatihi Bi Al Tahseel Fi Maddt Al Falsafa Laday Tullab Al Marhala Al Thanawiyya. Unpublished Master Dissertation, College of Education, Ain Al Shams University.

Atheem, A. R. (2008). Faaliya Namoozaj Muqtarih Qaim Ala Istratijiyyat Ma Wara Al Marifa Fi Tanmiyat Maharat Al Qira Lil Dirasa Wa Al Qira Al Ibdaiyya Laday Tullab Al Marhala Al Thanawiyya. Unpublished Doctorial research, Girl's College of Arts and Educational Sciences: Ain Al Shams University.

Bayat, S., \& Tarmizi, R. (2010). Assessing Cognitive and Metacognitive Strategies during Algebra Problem Solving among University Students. Procedia Social and Behavioural Sciences, 8, 403-410. http://dx.doi.org/10.1016/j.sbspro.2010.12.056

Carr, M., Kurtz, B. E., Schneider, W., Turner, L. A., \& Borkowski, J. G. (1989). Strategy Acquisition and Transfer among German and American Children: Environmental Influences on Metacognitive Development. Developmental Psychology, 25, 765-771. http://dx.doi.org/10.1037/0012-1649.25.5.765

Cattell, M. (1999). A Study of the Effect of Metacognition on Reading Comprehension (ERIC Document Reproductive Service no. ED491177).

El Hindi, A. (1993). Supporting College Learners: Metacognition, Locos of Control, Reading Comprehension and Writing Performance (ERIC Document Reproductive Service no. ED364852).

Everson, H. (1992). Exploring the Relationship of Test on Anxiety and Metacognition on Reading Test Performance (ERIC Document Reproductive Service no. ED363624).

Fahmi, I. (2003). Faaliyyat Istratijiyyat Ma Wara Al Maarifa Fi TanmiyatMaharat Al Qira Al Naqida Laday Talibat Al Saf Al Awwal Al Thanawi. Al QiraWa Al MaarifaMagazine, 23, 1-10.

Fisher, R. (2002). Shared Thinking: Metacognitive modelling in the literacy hour. Reading Literacy and 
Language. Oxford: UKRA Blackwell Publishers.

Flavell, H. (1981). Cognitive Monitoring. In W. P. Dickenson (Ed.), Children's Oral Communication Skills (pp. 35-60). New York: Academia.

Hassam, L. A. (2002). Faaliyat Istikhdam Istratijiyyat Ma Wara Al MarifaLitanmiyat Al Faham Al Qari Wa Al Tahseel Fi Madat Al Uloom Laday Talameeth Al Saf Al Thani Al Itiyadi. Al Tarbiya Al Ilmiya Magazine, 5, $1-125$.

Henson, K. T., \& Eller, B. F. (1999). Educational psychology for effective teaching (2nd ed.). Boston, London, New York: Wadsworth Publishing Company.

Jacobse, A., \& Harskamp, E. (2009). Student Controlled Metacognitive Training for Solving Word Problems in Primary School Mathematics. Educational Research and Evaluation, 15(5), 447-463. http://dx.doi.org/10.1080/13803610903444519

Jarwan, F. (2002). Taaleem Al Tafkeer, MafaheemWaTatbeeqat. Jordan: Dar Al Kitab Al Jami.

Kapa, E. (2002). A Metacognitive Support during the Process of Problem Solving in a Computerised $\begin{array}{llll}\text { Environment. Educational Studies in } & \text { Mathematics, 47(3), 317-336. }\end{array}$ http://dx.doi.org/10.1023/A:1015124013119

Koch, A. (2001). Training in Metacognition: Metacognition and Comprehension of Physics. Science Texts Education, 85(6), 758-768. http://dx.doi.org/10.1002/sce.1037

Leather, C., \& Mcloughlin, D. (2001). Developing Task Specific Metacognitive Skills in Literate Dyslexic Adults. Adult dyslexia and skills development centre. Retrieved from www.bdainternationalconference.org

Lin, X. (2001). Designing Metacognition Activities. Educational Technology Research and Development, 49(2), 23-40. http://dx.doi.org/10.1007/BF02504926

Livingston, J. A. (1996). Effects of Metacognitive Instruction on Strategy Use of College Students. Unpublished Manuscript, State University of New York at Buffalo.

Mayers, L. H. (1988). Analysis of Students'Outcomes in Ninth Grade Physical Science. Diss. Abs. Int., 50(H).

Miller, S. P., \& Mercer, C. D. (1997). Educational aspects of mathematics disabilities. Journal of learning disabilities, 30(1), 47-56. http://dx.doi.org/10.1177/002221949703000104

Murray, D. (1989). Expecting the Unexpected: Teaching Myself and Others to Read and Write. Portsmouth: Heinemann Educational Books.

Mustafa, H. (2004). Athar Istikhdam Istratijiyyat Ma Wara Al Maarifa Fi Tanmiyat Maharat Al Faham Al Qirai Laday Talibat Al Saf Al Awwal Al Itiyada Al Azhari, 4th Educational Conference. Al QiraWaTanmiyat Al Tafkeer, 7-8. Ain Al Shams University, Egypt.

Newman, D. R., Webb, B., \& Cochrane, C. (1995). A content analysis method to measure critical thinking in face-to-face and computer supported group learning. Interpersonal Computing and Technology, 3(2), 56-77.

Osman, R. (2004). Linking Reading and Writing: Concept Mapping and Organising Tactic. Retrieved from http://www.cete.org/acv/doc/tia00107

Ozsoya, G., \& Ataman, A. (2009). The Effect of Metacognitive Strategy Training on Mathematical Problem Solving Achievement. International Electronic Journal of Elementary Education, 1(2), 68-83.

Panaoura, A. (2007). The Impact of Recent Metacognitive Experiences on Pre-service Teachers' Self-representation in Mathematics and its Teaching. CERME 5, 329-338. Department of Pre-primary Education, Frederick Institute of Technology, Cyprus.

Panaoura, A., Gagatsis, A., \& Demetriou, A. (2009). An Intervention to the Metacognitive Performance Self-regulation in Mathematics and Mathematical Modelling. Acta Didactica Universitatis Comenianae Mathematics, 9, 63-79.

Phakiti, A. (2003). A Closer Look at Gender and Strategy Use in L2 Reading. Language Learning, 53(4), 649-702. http://dx.doi.org/10.1046/j.1467-9922.2003.00239.x

Qishta, A. (2008). Athar TantheefIstratijiyyat Ma Wara Al Maarifa Fi Tanmiyat Al Mafaheem Al Ilmiyya Wa Al Maharat Al Hayatiyya Bi Al Uloom Laday Talabat Al Saf Al Khamis Al Asasi in Gaza. Unpublished Master Dissertation, College of Education, Islamic University, Gaza, Palestine.

Rickey, D., \& Stacy, A. (2000). The Role of Metacognition in Learning Chemistry. Journal of Chemical 
Education, 77(7), 34-47. http://dx.doi.org/10.1021/ed077p915

Saad, A. (2002). Athar Istikhdam Istratijiyya Al Taallum Al Qaim Ala Al Istibtan Ala Tanmiyat Maharat Ma Wara Al Tafkeer Laday Tullab Al Saf Al Awwal Al Thanawi Min Khilal Madat Al Fizya, 6th Educational Conference. Al Tarbiya Al Ilmiya Wa Thaqafat Al Mujtama, 1, 28-31. Egyptian Educational University.

Scardamalia, M., \& Bereiter, C. (1991). Higher Level Agency for Children in Knowledge Building: A Challenge for the Design of New Knowledge Media. Journal of the Learning Science, 1, 37-68. http://dx.doi.org/10.1207/s15327809j1s0101_3

Shihab, M. A. M. (2000). Athar Istikhdam Istratijiyyat Ma Wara Al Marifa Fi Tahseel Al Uloom Wa Tanmiyat Maharat Amaliyyat Al Ilm Al TakamuliyyaWa Al Tafkeer Al IbtikariLadayTalameeth Al Saf Al Thalith Al Itiyadi. Al Tarbiya Al IlmiyyaMagazine, 3, 1-40.

Tajika, H. et al. (2007). Effects of Self-explanation as a Metacognitive Strategy for Solving Mathematical Word $\begin{array}{llll}\text { Problems. } & \text { Japanese } & \text { Psychological 222-233. }\end{array}$ http://dx.doi.org/10.1111/j.1468-5884.2007.00349.x

Touq, M. A., Qattami, Y., \& Adas, A. R. (2003). UsasIlm Al Nafs Al Tarbawi, 3. Amman: Dar Al Fikr Printers and Publishers.

Van Zile-Tamsen, C. M. (1996). Metacognitive Self-regulation and the Daily Academic Activities of College Students. Unpublished Doctoral Dissertation, State University of New York at Buffalo.

Yang, Y. (2002). Reassessing Readers' Comprehension Monitoring. Reading in Foreign Language, 14, 18-42.

\section{Notes}

Note 1. Elementary level: it is the base that they focus on to prepare for the following stages of their lives. It is a general stage that includes all the children of the community and provides them with the basics from pure thoughts, good direction, experience, knowledge and skills.

Note 2. Study skill strategies: a group of processes that the learner performs aimed to verify metacognitive requirements and they are: knowing the nature of the learners, their processes and aims and taking heed of the activity processes that should be performed in order to gain a specific result, with self-control in the learning process and directing it. With that the learner carries the responsibility of learning by themselves by using their knowledge, beliefs and thinking processes to turn the concepts and facts that can be used to resolve the problems that they face.

\section{Copyrights}

Copyright for this article is retained by the author(s), with first publication rights granted to the journal.

This is an open-access article distributed under the terms and conditions of the Creative Commons Attribution license (http://creativecommons.org/licenses/by/3.0/). 